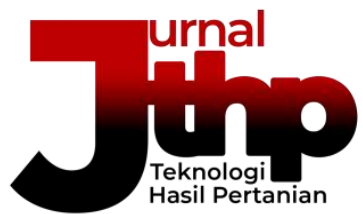

Jurnal Teknologi Hasil Pertanian. 13(2), 124-129

URL: https://jurnal.uns.ac.id/ilmupangan/article/view/43599

DOi: https://doi.org/10.20961/jthp.v13i2.43599

ISSN 1979-0309 (Online) 2614-7920 (Print)

\title{
CONVERSION OF DURIAN SHELL AGROINDUSTRIAL WASTE INTO VARIOUS VALUABLE PRODUCTS TO SUPPORT THE FOOD SECURITY DURING THE COVID-19 NEW NORMAL ERA: REVIEW
}

\author{
Ratna Dewi Kusumaningtyas ${ }^{1}$ and Ahmad Faiz Armiano Syah ${ }^{2}$ \\ ${ }^{1}$ Department of Chemical Engineering, Faculty of Engineering, Universitas Negeri Semarang, \\ Kampus Sekaran, Gunungpati, Semarang 50229 Indonesia \\ ${ }^{2}$ Agribusiness Study Program, Department of Agriculture, Faculty of Animal and Agriculture Sciences, \\ Diponegoro University, Jl Prof Sudharto, Tembalang, Semarang 50275 Indonesia \\ Email: ratnadewi.kusumaningtyas@mail.unnes.ac.id
}

Received [August 9, 2020]; Accepted [August 18, 2020]; Published [August 21, 2020]

\begin{abstract}
Durian (Durio zibethinus Murray) is a tropical, delicious and expensive fruit with specific aroma. Indonesia is among the biggest and the best durian fruit producer in the world. There are various types of Durian in Indonesia, coming from different areas. Based on the data released by the Central Bureau of Statistic, it was demonstrated that the main provinces producing durian in 2019 were East Java, Central Java, West Java, North Sumatera, West Sumatera, Banten, South Sulawesi, and South Sumatera with the total harvest of 289,334 ton, 172,939 ton, 94,183 ton, 90,105 ton, 62,564 ton, 46,436 ton, 45,729 ton, and 42,048 ton, respectively. The high production of durian fruit is beneficial for the agroindustrial and economic sectors. On the other hand, it also results in the abundance waste during the harvest time which causes many problems to the environment. The percentage of durian flesh of fruit is only $20.52 \%$, meaning that the $79.48 \%$ of durian is unutilized parts such as shell and seeds. The waste resulted from durian is about 556,360 ton per year. Durian waste, especially durian shell, is difficult to degrade. Hence, the proper waste management of the durian shell is crucial. The strategic way to manage the durian shell is by upgrading this waste into various valuable products. In this work, the innovation of the durian shell waste conversion into diverse product to support the national food security during the covid-19 new normal era is discussed Durian shell is potential to be used for the production of food products such as candy, pectin, edible film, and flour which is potentially further used for the crackers, noodle bread, cookie, and cake making. It also has potency to be utilized in the production of products which support the development of food crop agriculture and animal husbandry, such as biopesticides, organic fertilizer, and biochar, which strongly associated with the food supply security.
\end{abstract}

Keywords: durian shell, biomass waste, covid-19 pandemic, agriculture, upgrading

\section{INTRODUCTION}

Durian (Durio zibethinus Murray), also called as King of Fruit is a kind of delicious, exotic, expensive tropical local fruit which has a specific aroma such as ethyl (2S)-2methylbutanoate and 1-(ethylsulfanyl)ethane1-thiol (Li et al., 2017). Durian plant can be categorized as endemic commodity, and thus various variety of durian plant cultivated all over Indonesia (Belgis et al., 2017). Also as emphasized by Belgis et al. (2017), Indonesia is among the biggest and the best durian fruit producer in the world. Based on the data released by the Central Bureau of Statistic, it was shown that the total Indonesian durian production in 2019 were $1,169,804$ tons. As retrieved from the Minsitry of Agriculture of the Republic of Indonesia (2020), the main provinces producing durian in 2019 were East Java, Central Java, West Java, North Sumatera, West Sumatera, Banten, South Sulawesi, and South Sumatera with the total harvest of 289,334 ton, 172,939 ton, 94,183 ton, 90,105 ton, 62,564 ton, 46,436 ton, 45,729 ton, and 42,048 ton, respectively. The 
centers of durian plantation in Central Java are Banyumas, Purworejo, Candimulyo (Magelang), Banjarnegara, Pekalongan, as well as Brongkol and Gunungpati (Semarang), just to mention a few. The illustration of durian fruit is shown in Figure 1.

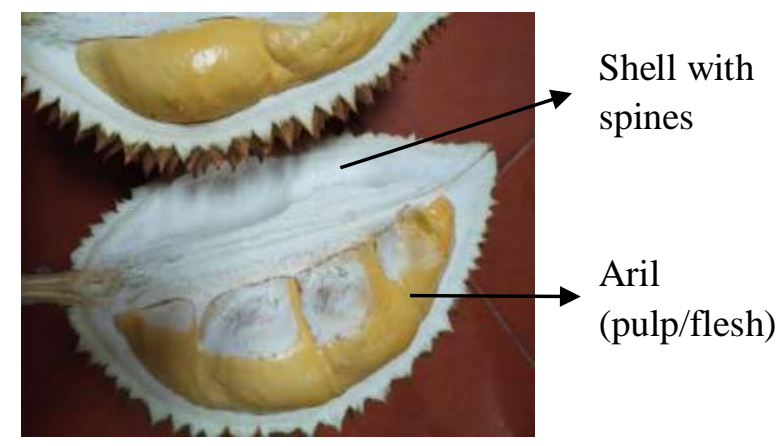

Figure 1 Parts of durian fruit

The high production of durian fruit in one hand is beneficial to support the growth of the agroindustrial and economic sectors. However, on the other hand, it also results in the abundance waste during the harvest time or durian season which causes many problems to the environment. According to Obeng et al. (2018), the percentage of durian flesh of fruit is only $20.52 \%$, meaning that the $79.48 \%$ of durian is unutilized parts such as shell and seeds. The waste resulted from durian is about 556,360 ton per year. Durian waste, especially durian shell, is lignocellulosic biomass which is composed of complex structure consisting of hemicellulose, cellulose, and lignin. They are strongly bonded that makes the durian shell difficult to degrade (Obeng et al., 2018). This agricultural waste is commonly disposed by burning or dumping it into the landfill, causing pollution to the environment. Hence, the proper waste management of the durian shell is crucial.

The strategic way to manage the durian shell is by upgrading this waste into various valuable products. There are many potential of durian shell to be converted into various products e.g. flour and cakes (Charoenphun and Kwanhian, 2019; Bhoosem and Bunyasawat, 2019), pectins (Wai et al., 2010; Maran, 2015; Haseem et al., 2019), bio-oil as renewable energy (Tan et al., 2019), materials for bacterial cellulose production
(Luo et al., 2017), fermentable sugar (Obeng et al., 2018), bio-battery (Khairiah et al., 2018) and biochar (Takolpuckdee, 2014), etc. Biochar can be used for varying application such as for adsorbent and soil amendment. In addition, durian shell can also be utilized as feedstock to produce food and agricultural needs such as fertilizer and biopesticide.

In the context of Covid-19 pandemic, food and agricultural support system are very crucial for the human survival during the pandemic and crisis period. Exploring the potency of durian shell waste for this purpose will provide two advantages, i.e enhancing both the environmental health and the food security. Thus, the discussion overviewing the published scientific articles taken from various databases regarding the utilization of durian shell is required. This paper emphasizes on the discussion of the innovation of the durian shell waste conversion into diverse product to support the national food security during the covid19 new normal era. At the end of the discussion, a recommendation for the further research is given.

\section{Durian Shell Upgrading to Food Products}

Durian shell is potentially used for the production of various food such as pectin, edible film, crackers, flour, and noodle. The prospect of durian shell valorization into flour and its application in bread, cookie, and cake making has been reported in the literatures.

Charoenphun and Kwanhian (2019) prepared durian flour by cutting, drying, and grinding the Thailand Monthong durian shell. The durian shell flour was then formulated with wheat flour and salted butter with certain composition to produce the gluten free cookies. Based on the consumer survey, the most favorable formula was provided by $10 \%$ durian shell flour, $47.5 \%$ wheat flour and $42.5 \%$ salted butter composition. The development of durian shell flour is a promising alternative to the wheat flour which is expensive, imported, and contains high gluten. It is also a choice for the consumers who have allergy with gluten.

Bhoosem and Bunyasawat (2019) studied the conversion of durian shell into 
flour as the replacement of wheat flour in butter cakes making. Durian shell flour demonstrated the high contain of crude fiber $(51.43 \%)$, which made it a prospective dietary fiber in food ingredients. The durian shell flour was used in the butter cake recipe with the amount of 5,10 , and $15 \%$. The sensory test to the consumers has exhibited that the butter cake formulated with durian shell flour were accepted in terms of appearance, aroma, taste, and texture. It implied that durian shell flour is a potential alternative and healthy flour which is suitable for food production during the pandemic era.

Durian shell is also potential as source of pectins. Pectins are important and complex polysaccharides which can be discovered in the cell wall of higher plant with white color and typically amorph and have characteristic as colloidal carbohydrate (Valdes et al., 2015). The extraction of pectins from durian shell has been studied by Wai et al. (2010), Maran (2015), and Haseem et al. (2019) using mild acid aqueous solution as solvent and $\mathrm{HCl}$ for $\mathrm{pH}$ adjusting. The optimum operation condition and yield of durian shell pectins extraction is demonstrated in Table 1.

Characterization of pectins extracted from durian was carried out by Haseem et al. (2019). It was revealed that durian shell pectin exhibited the moisture content, ash content, and water activity $\left(\mathrm{A}_{\mathrm{w}}\right)$ of $11.53 \%$, $4.67 \%$, and 0.452 , respectively, which fulfill the standard quality of food coating material. The conventional solid-liquid extraction process could result in low to high yield of pectins. To enhance the durian shell pectin yield, some process intensification in extraction method can be developed, such as the application of microwave, ultrasound, electromagnetic induction, and enzyme technology (Valdes et al., 2015).
Understanding the potential and good properties of durian shell pectins, it is valuable to upgrade the durian shell waste into agro pectins and to be used for the various applications in food industries in order to support the food security during the covid-19 pandemic era. Nevertheless, process optimization of pectin production is highly required.

The development of pectins from durian shell is important milestone of the valorization of durian shell. In food and pharmaceutical industries, pectins have a board range of application, for example as stabilizer, texturizer, emulsifier, thickeners, gelling agent, water binder, encapsulating agent, and crystallization inhibitors, etc. (Valdes et al., 2015). Pectins act as hydrating agent and sticking substance for the cellulosic network. Pectins have a unique characteristic that it is able to make gel in presence of $\mathrm{Ca}^{2+}$ ions or a solute at acid condition (Thakur et al., 1997).

Pectins extracted from durian's shells can also furthermore potentially used in the edible film manufacture. In food industry, the application of edible film has gained increasing attention since it can preserve antioxidative capacity of fruits to prolong their shelf-life. In addition, it can be used for other food coating which functions as a barrier of mass transfer such as humidity, oxygen dan light. Edible film is also applicable for coating many kinds of frozen food, which show increasing market opportunity during this pandemic covid-19 period. Pectine-based edible film has advantages in term of safety, biodegradability and eco-friendly characteristic, having nutrition content, and able to work as antimicrobe agent (Rosida et al., 2018).

Table 1 Optimum operation condition and pectin yield of the durian shell extraction

\begin{tabular}{lccc}
\hline & Wai et al. (2010) & Maran (2015) & Haseem et al. (2019) \\
\hline Origin of the Durian & Penang, Malaysia & Tamilnadu, India & Johor, Malaysia \\
Extraction Time & $4 \mathrm{hr}$ & $43 \mathrm{~min}$ & $1 \mathrm{hr}$ \\
$\mathrm{pH}$ & 2.5 & 2.8 & 2.5 \\
Temperature, ${ }^{\circ} \mathrm{C}$ & 80 & 86 & 85 \\
Solid-Liquid Ratio,g/mL & $1: 9$ & $1: 10.18$ & $1: 9$ \\
Yield, \% w/w & 10.3 & 9.1 & 73.67 \\
\hline
\end{tabular}




\section{Durian Shell Conversion to Fertilizer and Biopesticides}

Beside its prospect to be turned into various food products, durian shell waste also has potential to be utilized in the production of various products supporting the development of food crop agriculture such as biopesticides and organic fertilizer which strongly associated with the food security. Formulation of biopesticides from durian shell extract has been reported by Kusumaningtyas et al. (2020) and Harahap et al. (2019). Durian shell contains essential oil (EO) as secondary metabolite compounds which are toxic to insects, mosquitoes, and other pests. EO in durian shell can be isolated using extraction method. The cheap solvent for the extraction process is water. To produce biopesticide, durian shell EO were formulated with the other ingredients such as soursop leaves (Harahap et al., 2019) or garlic (Kusumaningtyas et al., 2020). It has been shown that the combination of durian shell EO and soursop leaves biopesticide was able to effectively exterminate aphids and on chili plants. Biopesticide application becomes more attractive to date as substitute for the synthetic pesticides which are harmful to the environment and human being.

Also, to support the development of organic farming, durian shell can be converted into organic fertilizer in the form of compost of biochar. Durian shell can be processed into compost simply by formulated it with sugar solution and Effective Microorganism (EM) to decompose the durian shell lignocellulosic material. Fauzi and Puspitawati (2017) found that durian shell compost fertilizer contained $14.6 \% \mathrm{C}$ organic, $1.69 \% \mathrm{~N}, 0.16 \% \mathrm{P}_{2} \mathrm{O}_{5}$, and $1: 20 \%$ $\mathrm{K}_{2} \mathrm{O}$ and it was effective to enhance the growth and yield of green cabbage.

In addition, durian shell can be utilized as soil improvement by converting it into biochar. Biochar is carbon-rich material which is produced through thermal decomposition of biomass in the presence of limited amount of oxygen and temperature under $700^{\circ} \mathrm{C}$. The process is named pyrolysis process (Nartey and Zhao, 2014). Biochar has various potential application, among the other is used for soil improvement or fertilizer. A vary of study on biochar soil amendment for enhancing the plant growth in agricultural sector has been found in the literature (Glaser et al.; 2014, Kizito et al., 2019; and Chew at al., 2020).

Specifically, valorization of durian shell into biochar fertilizer has been investigated by Takolpuckdee (2014) and Prakongkep et al. (2014). Takolpuckdee (2014) discovered that the durian shell biochar has good composition of $\mathrm{N}, \mathrm{P}, \mathrm{K}$ contents and could significantly enhance the growth of stem length and number of leaves. The addition of durian shell biochar with the ratio of durian shell biochar and soil of 3:4 provided the highest improvement on the morning glory plant growth compared to the addition of banana peel, mangosteen, and corncob biochars, as well as the addition of normal soil. Prakongkep et al. (2019) has examined the chemical characteristic of durian shell biochar as fertilizer. Durian shell as soil amendment can function as carbon sink and can act to enhance the crop yield. The crystalline mineral found in the biochar pore can serve as the plant nutrient elements. The main water soluble minerals found in durian shell biochar were sylvite $(\mathrm{KCl})$, kalicinite $\left(\mathrm{KHCO}_{3}\right)$, archerite $\left(\mathrm{KH}_{2} \mathrm{PO}_{4}\right)$, chlorocalcite $\left(\mathrm{KCaCl}_{3}\right)$ and struvite $\left(\mathrm{KMgPO}_{4} \cdot 6 \mathrm{H}_{2} \mathrm{O}\right)$.

In addition to its function as fertilizer, biochar is also an alkaline material that neutralizes acidic soil. It can be inferred that the application of durian shell fertilizer is beneficial to support the agronomic sector and, accordingly, enhancing the food security in Indonesia during the pandemic period. Nevertheless, to improve the properties of bio-char derived from durian shell, an inclusion of new technology, such as nanotechnology, is interesting for the future study. Many recent investigations reported the application of nanotechnology in the biochar fabrication (Khan et al., 2015, Tan et al., 2016; Kim et al., (2018). However, to the best of our knowledge, the application of nanotechnology in the fabrication of bio-char from durian shell has not been properly investigated. Thus, it may be interesting for the future research by the scientist. 


\section{CONCLUSION}

Indonesian durian shell waste is strategic to be valorized into food products and agronomy support products such as flour, pectins, biopesticide, and fertilizer. Nevertheless, some studies are still required in order to optimize the valorization of durian shell. As such, the development of various durian shell-based foods is needed for future studies. Also, it is suggested that the process intensification on the extraction process for pectin isolation is necessary to obtain higher pectin yields. In order to support farming practices, trajectory studies on the application of durian shell-based biopesticide in various plant are needed. Furthermore, durian shell-based biochar as soil amendment and can be re-designed using nano technology to produce biochar with more specific properties and higher performance as fertilizer.

\section{REFERENCES}

Belgis, M., Wijaya, C. H., Apriyantono, A., Kusbiantoro, B., and Yuliana, N. D. 2017. Volatiles and aroma characterization of several lai (Durio kutejensis) and durian (Durio zibethinus) cultivars grown in Indonesia. Scientia Horticulturae, 220, 291-298.

Bhoosem, C. and Bunyasawat, J. 2019. Nutritional Physical and Sensory uality of Butter Cake Substituted with Durian Rind Powder for Wheat Flour Replacement. RMUTP Research Journal, 13(1), 101-115.

Charoenphun, N. and Kwanhian, W. 2019. Production of Gluten Free Cookies Supplemented with Durian Rind Flour. Sci. \& Tech. RMUTT J., 9(2), 23-38.

Chew at al., 2020. Biochar-based fertilizer: Supercharging root membrane potential andbiomass yield of rice. Science of the Total Environment, 713, 136431.

Fauzi, A. R. and D. Puspitawati. 2017. Pemanfaatan KomposKulit Durian untuk Mengurangi Dosis Pupuk N
Anorganik pada Produksi Tanaman Sawi Hijau (Brassica junceae). Agrotrop, 7 (1), 22 - 30.

Glaser, B., Wiedner, K. Seelig, S., Schmidt, H. P., and Gerber, H. 2014. Biochar organic fertilizers from natural resources as substitute for mineral fertilizers. Agronomy for Sustainable Development, 35(2), 667-678.

Harahap, F., Bariyah, S., Sofyan, N. A., Simorangkir, M. 2019. Pemanfaatan limbah kulit durian dan daun sirsak sebagai biopestisida alami. Jurnal Biosains, 5(2), 83-91

Haseem, N. H., Mohamad Fuzi, S. F. Z., Kormin, F., Abu Bakar, M. F.. and Sabra, S.F. 2019. Extraction and partial characterization of durian rind pectin. Earth and Environmental Science, 269, 012019.

Khairiah, Siregar, S. M., Siregar, J., Nasution, L. A., and Daulay, A. H. 2018. The Electrical properties of nanomaterials derived from durian skin waste by using a various types of electrodes for bio-battery application. Journal of Physics: Conf. Series, 1120, 012085.

Khan, M. Y., Mangrich, A. S., Schultz, J., Grasel, F. S., Mattoso, N., and Mosca, D. H. 2015. Green chemistry preparation of superparamagnetic nanoparticles containing $\mathrm{Fe} 3 \mathrm{O} 4$ cores in biochar. Journal of Analytical and Applied Pyrolysis, 116, 42-48.

Kim, D. Y., Kadam, A., Shinde, S., Saratale, R. G., Patra, J., and Ghodake, G. 2018. Recent developments in nanotechnology transforming the agricultural sector: a transition replete with opportunities. Journal of the Science of Food and Agriculture, 98, 849-864.

Kizito, S., Luo, H., Li, J., Bah, H., and Wu. S. 2019. Role of Nutrient-Enriched Biochar as a Soil Amendment during Maize Growth: Exploring Practical Alternatives to Recycle Agricultural Residuals and to Reduce Chemical 
Fertilizer Demand. Sustainability, 11, 3211.

Kusumaningtyas, R. D., Wulansarie, R., Astuti, W., Hartini, N., and Richana, S. 2020. Community Empowerment on the Biopesticide Production from Durian Peel Waste. Proceedings of the 5th International Conference on Science, Education and Technology, ISET 2019, 29th June 2019, EAI Publisher, Semarang, Central Java, Indonesia.

Li, J. X., Schieberle, P. and Steinhaus, M. 2017. Insights into the key compounds of durian (Durio zibethinus L.'Monthong') pulp odor by odorant quantitation and aroma simulation experiments. Journal of Agricultural and Food Chemistry, 65, 639-647.

Luo et al. 2017. Efficient Using Durian Shell Hydrolysate as Low-Cost Substrate for Bacterial Cellulose Production by Gluconacetobacter xylinus. Indian $J$ Microbiol, 57(4), 393-399.

Maran, J. P. 2015. Statistical optimization of aqueous durian extraction of pectin from waste rinds. International Journal of Biological Macromolecules, 73, 9298.

Ministry of Agriculture of the Republic of Indonesia. 2020. Accessed on 12 August 2020 from https://www.pertanian.go.id/home/?sho $\mathrm{w}=$ page $\&$ act $=$ view $\&$ id $=61$

Nartey, O. D. and Zhao, B. 2014. Biochar Preparation, Characterization, and Adsorptive Capacity and Its Effect on Bioavailability of Contaminants: An Overview. Advances in Materials Science and Engineering, 24, 715398, 1-12.

Obeng, A. K., Premjet, D., and Premjet, S. 2018. Fermentable Sugar Production from the Peels of Two Durian (Durio zibethinus Murr.) Cultivars by Phosphoric Acid Pretreatment. Resources, 7, 60.

Prakongkep, N., Gilkes, R. J., and Wiriyakitnateekul, W. 2014. Agronomic benefits of durian shell biochar. Journal of Metals, Materials and Minerals, 24(1), 7-11.

Rosida, Sudaryati, and Yahya, A. M. 2018. Edible Film from the Pectin of Papaya Skin (The Study of Cassava Starch and Glycerol Addition). Journal of Physics: Conf. Series, 953, 012248

Takolpuckdee, P. 2014 . Transformation of Agricultural Market Waste Disposal to Biochar Soil Amendments. Procedia Environmental Sciences, 20, 64-70.

Tan, Y. L., Ahmed, M. J., Hummadi, E. H., and Hameed, B. H. 2019. Kinetics of Pyrolysis of Durian (Durio zibethinus L.) Shell Using Thermogravimetric Analysis. Journal of Physical Science, Vol. 30(Supp.1), 65-79.

Tan, X. F., Liu, Y. G., Gu, Y. L., Xu, Y., Zeng, G. M., Hu, X. J., ... and Li, J. 2016. Biochar-based nano-composites for the decontamination of wastewater: a review. Bioresource Technology, 212, 318-333.

Thakur, B. R., Singh, R. K., and Handa, A. K. 1997. Chemistry and Uses of Pectin - A Review. Critical Reviews in Food Science and Nutrition, 37(1), 47-73.

Valdés, A., Burgos, N., Jiménez, A., and Garrigós, A. C. 2015. Natural Pectin Polysaccharides as Edible Coatings . Coatings, 5, 865-886.

Wai, W. W., Alkarkhi, A. F. M., and Easa, A. M. 2010. Effect of extraction conditions on yield and degree of esterification of durian rind pectin: An experimental design. Food and Bioproducts Processing, 88, 209-214. 